\title{
Bribery case underlines Japan's bureaucracy
}

Tokyo. The bureaucratic stranglehold that Japan's Ministry of Education, Science and Culture holds over the country's universities has been highlighted by a bizarre case of corruption in the Japanese government. Last week, an official from the ministry was arrested on suspicion of having accepted a bribe of $¥ 500,000$ (US $\$ 4,500$ ) from senior officials at a small private university.

As a case of bribery, the incident is trivial compared with the corruption in other parts of the government that is reported almost daily. This can involve payments of tens or hundreds of millions of yen to win favours from government officials.

But the case stands out because of the peculiar purpose of the alleged bribe. Toshio Yamaura, 37, deputy chief of the ministry's Higher Education Bureau, has been accused of accepting the bribe to speed up the processing of a change of name of a faculty and its departments in Sugiyama Jogakuen University, a small university in Nagoya that started out as a sewing school in 1905.

Universities throughout Japan face a crisis because the population of 18-year-olds, having peaked at just over 2 million in 1992, is now rapidly declining, and is expected to fall to 1.5 million by the end of this decade. As a result, the hundreds of universities in Japan, especially the less well known private ones, are scrambling to make themselves more attractive to the dwindling student population to avoid being forced out of business by a lack of students.

The university in Nagoya wanted to change the somewhat old-fashioned name of its 'home economics faculty', which covers studies of food, nutrition, clothing and textiles, to the more fashionable 'school of life studies'. And within the faculty it also wanted to split the department of 'clothing and textiles' into two new departments, to be known as 'social science' and 'the human environment'.

In Japan, however, such changes need the official approval of the ministry of education in Tokyo. Such approval typically takes at least one year in the case of a department name, and two years for changes in a faculty. The president of one of Japan's leading national universities says it took him five years to re-name and re-organize several science departments in his university, and most of this time was spent clearing the ministry's procedures.

These regulations are just one element of a complex bureaucracy that extends from the ministry throughout Japan's universities, and is meticulously maintained by administrators posted to the universities from the ministry.

Faced with the imminent decline in the country's student population, officials at Sugiyama Jogakuen University, including the head of the board of trustees, Masahiro Sugiyama, seem to have been unable to accept a wait of several years. The university won approval for the name changes in

December 1990 only about six months after it had applied for them.

A few months later, according to police charges, Sugiyama and three other university officials paid the bribe to Yamaura, and subsequently took him on a sightseeing tour of the local countryside as a way of thanking him for his unusually speedy processing of their application.

Ryoko Akamatsu, Japan's education minister, who was not in office at the time of the alleged bribery, apologized at a news conference last week and said she was "astounded" by the incident. She promised that the ministry will do what it can to ensure that such an incident does not happen again. But she did not suggest that universities should be allowed to change the names of departments and faculties themselves.

David Swinbanks

\section{Milk hormone clears final hurdle}

Washington. The publication of a favourable report by the Clinton administration on the economic and social impacts of recombinant bovine somatotropin (rBST) has helped to clear the way for the Monsanto Company to begin marketing the drug to dairy farmers when a temporary ban on its sale is lifted two weeks from now.

With almost all congressional avenues for derailing the product now exhausted, it will now be up to farmers and consumers to decide whether this new aid for the dairy industry - which will appear under the trade name Posilac more than nine years after the company first applied for regulatory approval - sinks or swims.

The drug was approved for commercial use in the United States by the Food and Drug Administration (FDA) last November (see Nature 366, 192; 1993). But Congress imposed a 90-day ban on sales of rBST following its approval, during which time the administration agreed to undertake a study of its implications for consumers,

\section{Germany eases controls on gene experiments}

Munich. Germany has introduced a new law covering research in genetic engineering, overcoming a threat from the left wing of the opposition Social Democrats to block its passage through the German Parliament.

The law eases procedures for the authorization of genetic experiments. In particular it reduces substantially the amount of paperwork required for norisk and low-risk genetic experiments, long considered a powerful disincentive for the development of biotechnology and genetic engineering in Germany.

The Social Democrats (SPD), concerned that the law would reduce public accountability, has demanded more control of genetic experiments, particularly for field experiments with genetically modified organisms which may now proceed without a public hearing (see Nature $365,684 ; 1993)$. But 14 proposed amendments were overruled by their more conservative colleagues in the SPD-led Länder, who sit in the upper house, and who voted with the government. Alison Abbott dairy farmers and the economy.

The report, which was released in Washington last week, paints a rosy picture of the technology, and says that consumers and dairy farmers could stand to benefit from lower milk prices and an increase in milk yields per cow of 10-20 per cent.

But Senator Russ Feingold (Democrat, Wisconsin), one of five congressmen who had requested the study, and a vocal opponent of rBST on economic grounds, says he was "appalled at the bias of the report", which, in his view, "read like it was written in the Monsanto boardroom".

Feingold says that the report plays down the effect that rBST will have on the dairy industry and on the cost to the federal government for the milk price support programme, and focuses too heavily on the impact of the ban on Monsanto and the biotechnology industry as a whole.

For Monsanto, the only company of four so far to have obtained FDA approval to market rBST in the United States, the temporary ban has meant 90 days of lost sales and the opportunity to build market share before competing products are approved. Rather than flooding the market with free samples, Thomas McDermott, a spokesman for the company, says that Monsanto has spent the time educating farmers as to the benefits of rBST and distributing information to potential customers.

With the battle shifting away from Congress, Jeremy Rifkin of the Foundation on Economic Trends says that protest will now take the form of "an old-fashioned grassroots campaign". Starting on 3 February, he says, the battle will be waged in neighbourhoods, restaurants and at the grocery stores.

Diane Gershon 